\title{
ILLIBERAL IMMIGRANTS AND LIBERALISM'S COMMITMENT TO ITS OWN DEMISE
}

\author{
Daniel Weltman
}

This is the draft before copyedits. Final version is in Public Affairs Quarterly Vol. 34, No. 3 (July 2020), pp. 271-297 https://www.jstor.org/stable/26929785

\begin{abstract}
Can a liberal state exclude illiberal immigrants in order to preserve its liberal status? Hrishikesh Joshi has argued that liberalism cannot require a commitment to open borders, because this would entail that liberalism is committed to its own demise in circumstances according to which many illiberal immigrants aim to immigrate into a liberal society. I argue that liberalism is committed to its own demise in certain circumstances, but that this is not as bad as it may appear. Liberalism's commitment to its own demise is merely a reflection of the fact that it must take into account the rights of outsiders, not just the rights of existing citizens, and of the fact that circumstances of injustice can sometimes leave liberal societies with no correct choice.
\end{abstract}

What can a liberal regime do when faced with a situation that threatens to render the state illiberal and that can only be addressed by restricting freedom? Can a liberal state, which by definition is committed to upholding freedoms, compromise these freedoms for the sake of preserving its liberal nature? Or are some violations of freedom out of bounds for a liberal state, such that it must be committed to its own demise in some circumstances? 
I approach this question by exploring one particular instance in which we might think liberalism can protect itself. Hrishikesh Joshi argues that in the context of immigration restrictions, liberalism cannot be committed to its own demise: it is legitimate for a liberal state to restrict the right to immigrate in order to preserve the existence of the state in its liberal form. ${ }^{1}$ He claims that the liberal state may prevent immigration if doing so is necessary to prevent immigrants who hold and act on illiberal norms and beliefs from changing the nature of the state from liberal to illiberal. ${ }^{2}$ He presents this argument in opposition to Christopher Freiman and Javier Hidalgo's argument that liberalism is incompatible with restrictions on immigration. ${ }^{3}$ In part one of this article I recap Freiman and Hidalgo's argument and describe how my defense below is applicable not just to their view but to the debate over immigration more broadly. In part two I defend Freiman and Hidalgo and other open borders advocates against Joshi's arguments by showing that liberalism is committed to its own destruction in the case of immigration rights, at least in some possible cases. This is true not just for liberals who endorse open borders, but for all liberals. In part three I argue that this is not as implausible as it may seem. Part two focuses on Joshi specifically because he has put the point about self-destruction most forcefully. Part three is relevant to liberals more generally who might be inclined to reject

\footnotetext{
${ }^{1}$ Joshi, "Is Liberalism Committed to Its Own Demise?" Arash Abizadeh ("Democratic Theory and Border Coercion," 53) offers a similar but much briefer and more limited argument. Abizadeh's argument suggests that a liberal society can have some discretion with respect to border control for the sake of defending the rights of a particular minority culture, not for the sake of preserving liberalism broadly construed. Michael Blake ("The Right to Exclude," 535) mostly agrees with Joshi that liberalism is not a suicide pact, saying "there is no good in holding fast in the name of diversity if it causes the annihilation of democratic practice.' But he also thinks that in at least some cases (in which part of the blame rests on the existing citizens, rather than entirely on the potential immigrants) there is 'no particularly good answer to this dilemma.' See also Anna Moltchanova's discussion of a similar situation ("Cooperation in the We-Mode and Immigrant Inclusion").

${ }^{2}$ By 'immigration' I mean the right to enter a country and settle there for a long time. This may entail the right to citizenship if, as some have argued, a state cannot justify withholding citizenship from long-term residents. See Walzer, Spheres of Justice, chap. 2; Miller, National Responsibility and Global Justice, 225; Altman and Wellman, A Liberal Theory of International Justice, 177-78. It may even entail a duty to obtain citizenship: see De Schutter and Ypi, "Mandatory Citizenship for Immigrants."

${ }^{3}$ Freiman and Hidalgo, "Liberalism or Immigration Restrictions, But Not Both." See also Phillip Cole (Philosophies of Exclusion, 193): 'in both theory and practice liberal theorists and states apply non-liberal if not illiberal principles to outsiders.'
} 
open borders, or who might be inclined to endorse any particular immigration restrictions for reasons similar to Joshi's. Thus the conclusions of this article are relevant to anyone considering what it could mean for liberalism to be committed to open borders, or to any kinds of immigration restrictions or lack thereof. Part four addresses objections.

\section{FREIMAN AND HIDALGO AND THE IMMIGRATION DEBATE}

Briefly, I will recap Freiman and Hidalgo's argument for open borders. ${ }^{4}$ They argue that 'freedom of movement is plausibly on a par with other liberal freedoms,' and so 'if a state's right to self-determination grounds a prima facie right to restrict immigration, then it also grounds a prima facie right to restrict liberal freedoms such as speech, religion, sexual choice and more. ${ }^{5}$ They then argue that a liberal state cannot justify restricting freedom of movement by limiting immigration, because this restriction would unjustifiably infringe upon freedom. ${ }^{6}$ Thus a society which restricts immigration is an illiberal society.

The thought is that according to liberalism, the burden of proof is on someone who wishes to restrict liberty. Unless restrictions on liberty can be justified, a liberal society allows people to exercise this liberty. This is especially true of restrictions on negative liberty, which are restrictions which prevent someone from doing something, because many restrictions on

\footnotetext{
${ }^{4}$ Joshi makes some arguments against Freiman and Hidalgo that aren't addressed below. These arguments are focused on whether restrictions on movement are illiberal, and if they are, whether they are a particularly drastic violation of liberty ("Is Liberalism Committed to Its Own Demise?," 259-62). If these arguments work, then Freiman and Hidalgo's argument needs further defense if it is to succeed. I here assume (and thus do not argue) that a liberal defense of open borders can be provided, either of the sort Freiman and Joshi give or of some other kind, but many of my arguments below succeed even if liberalism does not entail open borders.

${ }^{5}$ Freiman and Hidalgo, "Liberalism or Immigration Restrictions, But Not Both," 1. They repeat the claim that freedom of movement is a basic liberty akin to freedom of association and occupation (3-4) but they make no attempt to substantiate the point due to lack of space. Instead they argue that freedom of movement is crucial to and thus entailed by other less controversial basic liberties like freedom of occupation and association, so even if one disagrees that freedom of movement is a basic liberty, one ought still endorse freedom of movement as a liberty which is as important as any basic liberty (4-6). I thank an anonymous reviewer from this journal for pushing me to clarify this point.

${ }^{6}$ Freiman and Hidalgo, "Liberalism or Immigration Restrictions, But Not Both,” 14-20.
} 
negative liberties are coercive and coercion must be justified. ${ }^{7}$ Specifically, immigration restrictions are coercive, because they stop people from going where they would like to go. The bar for justifying these restrictions is high: 'generally speaking, the kinds of reasons that can defeat the presumption of liberty are themselves liberty-based reasons,' which means that typically one must advert not just to any value at all but to some other liberty in order to justify a coercive restriction on negative liberty. ${ }^{8}$ Failure to offer some such justification is illiberal. Immigration restrictions have no such justification, and thus are incompatible with liberal society. A state can be liberal or restrict immigration but it cannot do both.

Freiman and Hidalgo thus have a strict understanding of negative liberty and the sort of restrictions on it that are compatible with liberalism. Without a strong libertarian understanding of freedom of movement and liberalism, it is hard to get their argument off the ground. For my purposes, though, this is unimportant. The only relevant point for the discussion below is the question of the compatibility of liberalism, on the one hand, and restrictions on immigration, on the other. My argument assumes that there could be some liberal argument against border restrictions, but this argument need not be the strong one Freiman and Hidalgo offer. Insofar as any candidate liberal argument against border restrictions entails the possibility of liberalism's demise, my argument below is relevant. I focus on Freiman and Hidalgo because they are the target of Joshi, but as I describe in part three below, my point applies more broadly.

Thus whether we endorse Freiman and Hidalgo's libertarian conception of freedom of movement, or if instead we endorse any other liberal account that entails any sort of limit on the state's right to block immigration, we face a challenge. If liberalism is ostensibly incompatible with immigration restrictions (either all of them, like Freiman and Hidalgo claim, or just some of

\footnotetext{
${ }^{7}$ Freiman and Hidalgo, "Liberalism or Immigration Restrictions, But Not Both," 3.

${ }^{8}$ Freiman and Hidalgo, "Liberalism or Immigration Restrictions, But Not Both," 3.
} 
them, as other liberals might claim) what do we say about a case in which illiberal immigrants threaten to destroy the liberal nature of a society? A liberal society will allow immigrants to vote and otherwise participate in society in ways they see fit. They may vote for illiberal policies or convince others to endorse illiberal views. Must liberalism acquiesce to its own destruction?

\section{JOSHI'S TWO ARGUMENTS AGAINST THINKING LIBERALISM IS COMMITTED TO}

\section{ITS OWN DEMISE}

Joshi gives two reasons for thinking that liberalism cannot be committed to policies that foreseeably lead to its own demise and for thinking it therefore cannot be true that liberalism is committed to open borders or any other immigration policy which could spell the end of a liberal state. ${ }^{9}$ Both fail to establish this. What they instead establish is that there are circumstances under which liberalism might be committed to its own demise, and therefore we have to weigh the costs and benefits of this demise to see what a liberal society should do. ${ }^{10}$ Or, in other words, Joshi attempts to show that a liberal society can never be committed to its own demise, and that therefore a liberal society cannot be committed to open borders. But his arguments fail to establish this. Moreover, all forms of liberalism, not just the ones committed to Freiman and Hidalgo's libertarianism or open borders, entail at least the bare possibility that a liberal society can be committed to its own demise, or so I shall argue.

\footnotetext{
${ }^{9}$ A sort of companion to Joshi's argument would be the democratic stability argument advanced by Thomas Christiano ("Immigration, Political Community, and Cosmopolitanism"), which suggests that there could be a cosmopolitan justification for limiting immigration if immigration would destabilize democratic states which are crucial to the formation of a cosmopolitan political community. For discussion see Miklosi's "Immigration and the Democratic Stability Argument.” See also Mendoza, "Does Cosmopolitan Justice Ever Require Restrictions on Migration?"

${ }^{10}$ One class of arguments that Joshi does not moot is that liberalism might have a right to prevent its own destruction in these cases because societies more generally have a right to bar immigrants who do not intend to adopt the culture of their new society (Kymlicka, Multicultural Citizenship; Miller, On Nationality) or who are going to damage the life plans of existing citizens (Stilz, "Settlement, Expulsion, and Return"). Since these arguments are not tied up directly with liberalism and the right to immigrate, I set them aside.
} 


\subsection{THE FIRST ARGUMENT: THE VALUE OF LIBERAL SOCIETIES}

Joshi's first argument is that 'liberal societies are intrinsically valuable given the relationships between coresidents that they embody. Liberal societies are also instrumentally valuable insofar as they promote certain kinds of cultural and scientific achievements, given the ability of individuals to speak, think, and associate in a relatively free way. They also stand as a model for other, less liberal societies to emulate. ${ }^{11}$ It's not clear how the argument establishes the conclusion it is aiming for, which is that liberal societies cannot be committed to policies that entail their own destruction. Perhaps the thought is something like this:

Premise 1: If something is intrinsically and instrumentally valuable in various ways, it cannot be committed to its own demise.

Premise 2: Liberal societies are intrinsically and instrumentally valuable in various ways.

Conclusion: Liberal societies cannot be committed to their own demise.

Premise 1 is the weak link in this argument. Consider a soldier sacrificing themselves to save others, self-destructing experimental works of art, limited romantic encounters like one-night stands, or political organizations that exist solely to combat an injustice and which will gladly disappear absent this injustice. All of these are good candidates for things with intrinsic and instrumental value. They are also all committed to their own demise, either in the strong sense of actively aiming to achieve this demise, or in the weak sense of being committed to actions which will foreseeably bring about this demise. Consider for example the painting 'Girl with Balloon' by the artist Banksy, which was secretly outfitted with a mechanism that caused it to shred itself while it was being auctioned off. There's no reason to think artwork like this cannot be

\footnotetext{
${ }^{11}$ Joshi, "Is Liberalism Committed to Its Own Demise?," 264. This argument has much in common with an earlier argument made by Joseph Carens ("Migration and Morality: A Liberal Egalitarian Perspective"). For a response to Carens see Cole, Philosophies of Exclusion, 142-44.
} 
intrinsically and instrumentally valuable, despite being committed to its own demise in the strong sense. The soldier may be rationally committed to death in the weak sense, if this is the only way to save others, and this hardly calls into question the soldier's intrinsic or instrumental value. Therefore, things that are committed to their own demise in the strong sense of actively pursuing it (like a self-destructing work of art) or in the weak sense of acting in a way that foreseeably brings it about (like a soldier sacrificing themselves) can still be valuable both instrumentally and instrinsically. ${ }^{12}$

There is also very little positive to say in support of premise 1. At best it seems like a hope or a wish about how things might be rather than an obviously true feature of the normative landscape. Contrary to the hope expressed in premise 1, it may unfortunately be the case that some valuable things are committed to their own demise. It would be nicer if they weren't, but they are. It is not clear how we can rule out this possibility in every case. It may also be false that the commitment to demise is a bad thing. In some cases, like the self-destructing work of art and the one-night stand, the commitment to demise may be one of the reasons that the thing has instrumental and intrinsic value in the first place. Richard Arneson, for instance, suggests that 'it may be a necessary condition for some types of relationships having noninstrumental value that they do not give rise to special responsibilities and are not regarded by their participants as doing so,' such that a one-night stand might be valuable to some people only insofar as it will meet its demise rather than turning into a deeper relationship. ${ }^{13}$

To rehabilitate premise 1 , consider premise $1^{*}$ :

Premise $1 *$ : If something is intrinsically and instrumentally valuable in various ways, and if its demise would be detrimental, and if its demise is avoidable, and if this thing can be

\footnotetext{
${ }^{12}$ I thank an anonymous reviewer from the Journal of Global Ethics for suggesting I clarify the notion of being committed to demise.

${ }^{13}$ Arneson, "Extreme Cosmopolitanisms Defended," 561.
} 
constituted such that it is not committed to its own demise, and if being so constituted would not lead to an outcome worse than its own demise, and if being so constituted would not vitiate its intrinsic and instrumental value, it cannot be committed to its own demise.

Premise $1^{*}$ solves all of the important problems with the first premise of the argument. But it gives rise to problems in premise $2^{*}$, which is premise 2 modified so that, in conjunction with premise $1^{*}$, it entails the conclusion. Here is the argument again, this time with premises $1^{*}$ and $2 *$ :

Premise $1 *$ : As above.

Premise $2 *$ : Liberal societies are intrinsically and instrumentally valuable in various ways, and their demise would be detrimental, and their demise is avoidable, and liberal societies can avoid being committed to their own demise, and being so constituted would not lead to an outcome worse than their demise, and being so constituted would not vitiate their intrinsic and instrumental value.

Conclusion: Liberal societies cannot be committed to their own demise.

Premise $2^{*}$ raises a number of issues. Let's grant for the sake of the argument that the demise of a liberal society due to immigration and subsequent illiberal actions on the part of many immigrants would be detrimental. Let's also grant that such demise is avoidable. This leaves us with two problems.

First, premise $2 *$ now begs the question: it asserts that liberal societies can be constituted such that they are not committed to their own demise, but the linchpin of Freiman and Hidalgo's argument is that any society so constituted is not a liberal society. That is, any society that restricts immigration so as to prevent its own demise is, according to Freiman and Hidalgo, no 
longer a liberal society, just like a society that institutes martial law and restrictions on freedom of speech, movement, and religion in order to prevent its own demise is no longer a liberal society. This is true of any other argument which suggests an incompatibility between liberalism and some candidate immigration restrictions.

Second, premise $2 *$ asserts that the downsides of a liberal society's demise would not be outweighed by the upsides of the demise, like an increased standard of living on the part of the immigrants who have come from a poor society to live in a rich society with better employment prospects. But it is not obvious that the liberal society's demise will be always bad enough to outweigh the good results of immigration.

The failures of this argument point us to two areas of inquiry. First, it may be the case that restrictions on immigration which are necessary to 'preserve' liberal society in fact lead to its demise, because a society with these restrictions is for this very reason no longer a liberal society. So it's not just the consequences, or the ends, of preserving liberalism that we must keep in mind. It is also the means by which we do so, because liberalism, if it means anything, rules out certain means, namely the illiberal ones. ${ }^{14}$ Second, we can't just look at the downsides of the demise of a liberal society. These downsides must be balanced against potential upsides. If we don't look at the upsides, then perhaps we can use the downsides to explain why a liberal society can't possibly be committed to its own demise. If we look at the upsides, though, we might find a case for thinking liberal societies are sometimes so committed.

\footnotetext{
${ }^{14}$ Compare Arash Abizadeh's discussion of the case in which a democracy must resort to non-democratic principles to exclude certain people in order to remain stable: 'if rights of participation are denied to some on the instrumental grounds that doing so is, as a matter of empirical fact, necessary to preserve the vitality or stability of democratic institutions, one should bite the bullet: The right conclusion is that, under these circumstances, the ideal of collective self-rule and the democratic legitimacy of outcomes have been compromised - not that exclusion is constitutive of them' ("On the Demos and Its Kin," 877-78).
} 


\subsection{THE SECOND ARGUMENT: LIBERTY-BASED REASONS TO RESTRICT LIBERTY}

Joshi's second argument is more compelling. He argues that 'there seem to be libertybased reasons to restrict the freedom of movement of people from theocracy seeking to migrate to liberal democracy — namely that doing so will preserve the liberties that citizens of liberal democracy enjoy. The aim of maintaining and promoting the existence of liberal polities is a liberty-based aim. ${ }^{15}$ This in effect admits the second conclusion of my argument above: to determine whether liberalism is committed to its own demise, we have to weigh the liberty violations against each other. There are liberty-based reasons on each side: liberty-based reasons to think that the liberal society must admit the immigrants (and thus must be committed to its own demise) and liberty-based reasons to think that the liberal society can bar the immigrants. Joshi suggests that the balancing act is rather straightforward and that it tells in favor of barring the immigrants in cases where their arrival would cause the collapse of liberalism. I do not think we can conclude this so easily.

First of all, there are cases in which the balancing act clearly tells in favor of the liberal society's demise. If preserving the liberal society comes at the cost of thousands or millions of innocent lives, it's got to be curtains for the liberal society. If, for instance, admitting thousands of Jewish refugees during the Holocaust would have turned a liberal society into an illiberal but otherwise decent society, and if there were no other options besides admitting the refugees or sending them back to territory controlled or soon to be controlled by the Nazis, that society would still have had a duty to admit the refugees. ${ }^{16}$ This conclusion finds support from the fact

\footnotetext{
${ }^{15}$ Joshi, "Is Liberalism Committed to Its Own Demise?," 264. This argument shares much in common with an earlier argument by Frederick Whelan ("Citizenship and Freedom of Movement"). For Cole's response see Philosophies of Exclusion, 144-46.

${ }^{16}$ Concerns about whether the immigrants would assimilate and become good Americans animated the Immigration Act of 1924 in the United States, which purposely adjusted quotas to make sure only very small numbers of Eastern Europeans could immigrate. These restrictive quotas were one reason many Jews attempting to flee the Holocaust were denied entry to the United States. Former US Attorney General Jeff Sessions praised the law in a 2015
} 
that thinkers on all sides of the immigration debate, including those most amenable to the right to block immigration, still support a duty to admit refugees if there are no other options besides death or something almost as bad. ${ }^{17}$ As Luara Ferraciolo puts it, 'the state's right to exclude is only a prima facie one, since at times, justice requires the inclusion of those fleeing human rights violations at the hands of their government' - 'members of the [liberal] state can prioritize their own domestic interests so long as they concomitantly protect and promote the basic human rights of non-members,' and refugees must be admitted in order to protect and promote their basic human rights. ${ }^{18}$ If one cannot protect the basic rights of the refugees then there is no justification for prioritizing the interests of the members of the liberal state. So, in principle there are cases where liberalism is committed to its own demise. The task is now to elucidate the scope of these cases. It begs the question against supporters of open borders or others who argue against immigration restrictions to assume the answer will always tell in favor of preserving liberalism rather than admitting immigrants, just like it would beg the question against supporters of the freedom of speech to assume that a liberal society always has a right to restrict speech so as to preserve its liberal nature.

\footnotetext{
interview with white supremacist Steve Bannon (Serwer, "Jeff Sessions's Unqualified Praise for a 1924 Immigration Law"). I do not mean to unfairly paint Joshi as an ally of bigots: the point is just to note that we should be very careful about justifying exclusion on the basis of unfavorable features of the excluded, because this practice has both an extremely objectionable history and a present unsavory following. See also the discussions of how liberalism has been used as an excuse to support racist citizenship policies in Gibney ("Should Citizenship Be Conditional?," 652) and in Cole (Philosophies of Exclusion, 85 fn58).

${ }^{17}$ Altman and Wellman, A Liberal Theory of International Justice; Miller, Strangers in Our Midst; Pevnick, Immigration and the Constraints of Justice, 102-3. I am not claiming that these thinkers think that liberalism is committed to its own demise in this sort of circumstance. Rather, I am pointing out that everyone acknowledges the compelling nature of the claims of refugees, and it is in light of how compelling these claims are that, in extreme cases, they can outweigh some claims of existing residents of a liberal society. Walzer is something of an exception: 'communities must have boundaries; and however these are determined with regard to territory and resources, they depend with regard to population on a sense of mutual relatedness and mutuality. Refugees must appeal to that sense. One wishes them success; but in particular cases, with reference to a particular state, they may well have no right to be successful' (Spheres of Justice, 50). Even he makes an exception for refugees who have made it to their destination state, though, even if there are very large numbers of them: see Walzer, 50-51.

${ }^{18}$ Ferracioli, "Citizenship for Children: By Soil, by Blood, or by Paternalism?," 2866.
} 
Moreover, as the example of limitations on free speech highlights, there are nonimmigration cases in which liberalism is necessarily committed to its own demise, because both sides of the balancing act result in conclusions that violate liberty so much that the resulting society is no longer liberal. If, for instance, a liberal society divided between two violent religious sects has to choose between harshly restricting various freedoms or undergoing a civil war and the subsequent establishment of a theocracy by the victorious sect, then this society cannot remain liberal. This is easiest to see in a situation analogous to the one Joshi imagines which depends not on immigration but on an ideological shift. Joshi imagines a liberal society becoming illiberal when one hundred million illiberal people immigrate into the society. We can also imagine a liberal society becoming illiberal when one hundred million existing citizens change their preferences and begin acting according to illiberal norms and beliefs and voting for illiberal policies. The liberal society in the latter case may face two equally illiberal options: take away voting rights, freedom of speech, and freedom of association from the illiberal people and potentially even denationalize and deport them if necessary, or let the illiberal people turn the society illiberal. Either way the society is no longer liberal. ${ }^{19}$

\subsubsection{GREATER AND LESSER LIBERTY VIOLATIONS}

Joshi considers this second case and offers two responses. The first response is that 'some measures are greater violations of individual liberty and autonomy than others, and thus require a greater burden of justification. Sin taxes are restrictions on liberty but stand in need of less

\footnotetext{
${ }^{19}$ Compare Sahar Akhtar's discussion of denying citizenship to illiberal potential immigrants versus stripping citizenship from illiberal existing citizens ("Stripping Citizenship," 22-23). See also Cole's discussion of the topic (Philosophies of Exclusion, 142-48). Analogies between existing citizens and excluded outsiders also form the basis of Freiman and Hidalgo's original argument. We can also imagine the reverse of the exclusion argument: a liberal society is facing a slide into illiberality because its most liberal citizens are going to emigrate. Can this society restrict their freedom to exit and still remain liberal? See Cole, 47-48.
} 
justification than restrictions on freedom of speech, for example. Likewise, while granting that border controls involve restricting would-be migrants' liberty, such controls stand in need of less justification than moves to deport long-term residents. ${ }^{20}$ For this response to work, we must judge that the liberty restrictions on the potential immigrants are not so great as to outweigh the good results of making sure the state remains liberal. It doesn't make sense, though, to compare liberty losses on both sides only with respect to the right to movement of outsiders, since as we saw above, there can be cases where the stakes are much higher than just rights to movement for the people who are not allowed to immigrate. They may be facing death due to genocide or something similar. ${ }^{21}$ So, what requires justification is not just the bare act of refusing entry to potential immigrants. Rather, what requires justification is the state's acquiescence to the results of refusing entry.

Of course, it's not the case that a state is morally responsible for everything that happens to immigrants when they are denied entry. Even in cases of genocide, but especially in cases where the downsides of being refused entry are 'merely' severe impoverishment, lack of opportunity to better one's life, lack of freedom of the sort afforded by the new society, and so on, we might think that the state has no obligation to remedy this situation and thus it should not have to factor these results into the balancing act between preserving liberalism on the one hand and avoiding the violation of the rights of the potential immigrants on the other. To determine what the state is morally responsible for, we need a theory of global justice. Many cosmopolitan theories of global justice, for instance, entail strong duties of wealth redistribution, duties which can be partially discharged by allowing people to immigrate. This is the cosmopolitan justice

\footnotetext{
${ }^{20}$ Joshi, "Is Liberalism Committed to Its Own Demise?," 264.

${ }^{21}$ That Joshi's response is directly to Freiman and Hidalgo perhaps obscures this issue, because Freiman and Hidalgo base their entire argument on freedom of movement. But there can be many other liberal arguments in defense of a right to immigrate beyond the libertarian freedom of movement argument that Freiman and Hidalgo give.
} 
argument for open borders. ${ }^{22}$ Strict libertarian theories of justice, of the sort that Freiman and Hidalgo endorse, entail strong negative duties not to restrict certain sorts of freedoms, including the freedom to immigrate. ${ }^{23}$ All sorts of theories of global justice can include duties to prevent or alleviate genocide and other crimes against humanity to some degree.

This all points to a hole in Joshi's argument. To claim that preventing immigration has a much less dire impact on potential immigrants than deporting existing citizens or taking away their voting rights, Joshi commits to the following three claims: 1) being denied entrance into a state is not particularly egregious in ways that the liberal state has a duty to avoid; 2) being deported from a state or denied the rights to speech, vote, and assembly vote are very egregious in ways that the liberal state has a duty to avoid; and 3) the balance of these two things counts in favor of doing the former and not in favor of doing the latter, even if the results of failing to do these two things are otherwise identical. So for instance even if the person denied a right to immigrate and the person deported from the liberal state would end up leading equally benighted lives, we need to think that the liberal state has a duty only to avoid this outcome with respect to the current resident of the state. ${ }^{24}$

All three of these claims could be contested. If we are cosmopolitans or if we have some other reason to think that the state has some special responsibility towards the immigrants (because they are refugees, or because the state committed injustices against the region they hail from, or for some other reason) then the first claim is shaky. A cosmopolitan who thinks that

\footnotetext{
${ }^{22}$ Carens, The Ethics of Immigration.

${ }^{23}$ Huemer, "Is There a Right to Immigrate?"

${ }^{24}$ Matters are further complicated if we look at immigrants who have already made it into the state and whom the state is looking to deport. It may be that the state has greater duties to people already present (including people present in violation of the law) or that the state has certain duties with respect to internal immigration enforcement that would give it greater duties to these immigrants than to immigrants on the other side of the border. See Ferracioli, "Citizenship Allocation and Withdrawal: Some Normative Issues"; Ochoa Espejo, "Taking Place Seriously: Territorial Presence and the Rights of Immigrants"; Blake, "Immigration, Jurisdiction, and Exclusion"; Buckinx and Filindra, "The Case against Removal: Jus Noci and Harm in Deportation Practice"; Bosniak, "Being Here: Ethical Territoriality and the Rights of Immigrants."
} 
states must do their fair share to help out the needy on a global scale, and who thinks this duty can be satisfied by allowing the needy to immigrate, will see a relatively large injustice when someone needy is turned away at the border. With respect to claim two, some deportations need not be particularly egregious violations of rights, like deportations of people who spend much of their lives in another country anyways and deportations of people with few family ties or other ties to the state. Most relevantly, the third claim is not an easy calculation to make. If the state the immigrants come from is bad enough, and the illiberal society that would result if they immigrate is good enough (like Rawls's 'non-liberal but decent' societies), ${ }^{25}$ and if the state the current citizens would be deported to is one in which they would be relatively happy, then we might imagine someone endorsing immigration on the one hand and also endorsing deportation on the other hand. Or at least we might imagine someone endorsing immigration and for similar reasons (the adequate goodness of the illiberal society that would result) refusing to endorse deportation. None of this is ideal, because of course we'd prefer a liberal society that does not need to block immigration or deport anyone, but by hypothesis this is not an option. ${ }^{26}$

\subsubsection{PRACTICAL ISSUES WITH RESTRICTING RIGHTS}

Joshi gives a second argument to defend a liberal society's inability to take away the rights of its citizens and potentially deport them, while still being justified in blocking immigration. He suggests that 'some restrictions on liberty, even if they are to be tolerated in principle, are more prone to practical difficulties than others. Controlling immigration has less

\footnotetext{
${ }^{25}$ Rawls, The Law of Peoples, 3.

${ }^{26}$ Thus Joshi fails to note that even his own example entails liberalism's commitment to its own destruction: deportation and denial of speech, association, and voting rights are restrictions on freedom so large as to render a society illiberal if it avails itself of these options. But in the case we are considering, a society that fails to avail itself of these options also ends up illiberal. So, in at least some cases, liberalism is committed to its own demise. Joshi likely misses this point because he intends this argument to work in conjunction with his second argument, discussed below, rather than on its own.
} 
potential for institutional slippery slopes than controlling the speech of even extremely illiberal elements. Restrictions on speech, in other words, are ripe for abuse in a way that legal restrictions on immigration are not. ${ }^{27}$

For starters, this may be a false empirical claim. Many sorts of restrictions on immigration seem prone to many sorts of abuse, like religiously-targeted immigration restrictions that function as a way of inciting bigoted and nationalistic sentiments among inhabitants of a state (the so-called 'Muslim Ban' in the United States is one example) or immigration restrictions that are based on ethnicity which inflame and sustain racism and other ills (like the Chinese Exclusion Act, again in the United States). ${ }^{28}$ And there are certainly slippery slopes from immigration bans aimed at people outside the community to observation, detention, and deportation of people inside a community, including immigrants who are authorized to be there and citizens. Consider the United States's objectionably-named 'Operation Wetback,' the 1950s forced deportation of masses of Mexicans and people of Mexican ancestry, including many who were in the US legally and many who were US citizens, which was lauded by Donald Trump during his presidential candidacy in $2015 .{ }^{29}$ Efforts at combating immigration can go hand in hand with efforts to control politics within the state, as evidenced by the recent surveillance of

\footnotetext{
${ }^{27}$ Joshi, "Is Liberalism Committed to Its Own Demise?," 264-65.

${ }^{28}$ Lindauer, "Immigration Policy and Identification across Borders," 281. Other immigrant-centric policies are ripe for abuse in other ways, like for instance the fixation of conservative politicians and media outlets in the US on the so-called "migrant caravan" in Mexico immediately prior to the 2018 midterm elections, which one might plausibly think was done not on the basis of concern over the asylum seekers themselves but as a way of scaring voters into voting for conservative candidates. Even just having an immigration enforcement system can entail abuse, as when Customs and Border Patrol flew a border surveillance drone over Minneapolis during protests over police violence. See Holt, "CBP Flew a Predator Drone Over Minneapolis Amid George Floyd Protests."

${ }^{29}$ See CNN, "Trump Praises Operation Wetback" and Reston, "How Trump's deportation plan failed 62 years ago." Deportation is technically not the same as preventing immigration, but the point applies to immigration restrictions too. Moreover, divorcing immigration policy (like restrictions) from its implementation (which will entail deportation, harassment of non-immigrants, and other injustices) may be the wrong way to approach the topic. See Mendoza, "Enforcement Matters"; Cole, Philosophies of Exclusion, 10-11. Cole also has a broader discussion of the objectionable origins and features of many immigration laws in Cole, 30-31.
} 
US journalists carried out in conjunction with immigration control agencies like Immigrations and Customs Enforcement and Customs and Border Protection. ${ }^{30}$

In addition to depending on a rather tendentious empirical claim, Joshi's argument faces three theoretical difficulties. First, the argument has to admit that in principle, a liberal state can take away freedom of speech, freedom of association, and the right to vote. It can even deport its own citizens. This is because the argument depends on the practical difficulties of taking away the right, and if this is doing any work, it must be the case that the practical difficulties alone are the bulwark against taking the right away. This means that there are no in principle reasons against taking the right away. Of course, Joshi can say there are also in principle reasons, but this argument is assuming those do not exist, because otherwise the argument is otiose. As noted above, this argument assumes that the restrictions on rights 'are to be tolerated in principle. ${ }^{, 31}$ Indeed, the argument is committed to this being in principle acceptable to carry out not against a radical violent fraction of the populace but against the vast majority - one hundred million people in a state of one hundred ten million. I do not know what criteria Joshi has in mind for what counts as a liberal state, but it is fair to say that a state that is permitted to deny fundamental rights to the vast majority and then deport them is not a liberal state if the only thing holding it back from doing this is that such actions are 'prone to practical difficulties. ${ }^{32}$ A liberal state is not a state that can't find a practical way to take away rights to speech, association, and suffrage, even though it is perfectly justified in doing so, should it so choose. A liberal state is a

\footnotetext{
${ }^{30}$ Jones, Payton, and Feather, "Source: Leaked Documents Show the U.S. Government Tracking Journalists and Immigration Advocates Through a Secret Database." The aforementioned drone surveillance during domestic protestors is another example.

${ }^{31}$ Joshi, "Is Liberalism Committed to Its Own Demise?," 264. I thank an anonymous reviewer for this journal for urging me to clarify this point.

${ }^{32}$ Freiman and Hidalgo provide their own description of what it is to be a liberal state: endorsement of protection for some basic liberties, the placement of the burden of proof on those who would restrict liberty, and a requirement that restrictions on liberty be justified only for the sake of liberty ("Liberalism or Immigration Restrictions, But Not Both," 2-3). One need not have requirements this strong to object to Joshi.
} 
state that cannot justifiably take away these rights, or at least that cannot take them away from the vast majority. If for instance liberalism requires that 'all aspects of the social should either be made acceptable or be capable of being made to every last individual,' the aspect of society that entails granting me rights merely because it would be practically difficult to take them away is likely to render a society illiberal. ${ }^{33}$ Joshi argues that it's implausible for liberalism to treat all rights as absolute prohibitions. ${ }^{34}$ Be that as it may, it's equally implausible for liberalism to treat rights as something that can in principle (if not in practice) be taken away from the vast majority of citizens merely for the sake of preserving 'liberalism.' What sort of liberalism is preserved if less than ten percent of the population has the rights to free speech, to suffrage, or even to citizenship in principle? Moreover, the problem need not be cast in terms of inviolable (or nearinviolable) individual rights. It could instead be cast in terms of the value of equality: liberalism's commitment to freedom might be a commitment to equal freedom for all, or something approximating it. ${ }^{35}$ Thus the issue is not licensing the in principle violation of anyone's rights in particular but the drastically unequal situation that results when the rights of the many are in principle violable and the rights of the few are not.

The second theoretical difficulty for Joshi's argument is that it suggests that rights violations are wrong to the extent that they are ripe for abuse when used against citizens. Conversely, then, rights violations are not wrong if they are not ripe for abuse. ${ }^{36}$ The thought, then, is that a liberal society can restrict immigration to defend itself from demise without rendering itself illiberal, but it cannot restrict freedom of speech to defend itself from demise

\footnotetext{
${ }^{33}$ Waldron, "Theoretical Foundations of Liberalism," 128.

${ }^{34}$ Joshi, "Is Liberalism Committed to Its Own Demise?," 265.

${ }^{35}$ Banai, "Self-Determination and Resource Rights," 16. Allen Buchanan (Secession, 27-8) provides another discussion of how to cast a discussion like this in terms of values rather than rights.

${ }^{36}$ Joshi can't deny this converse, because then his argument would not show why it's okay to violate the rights of immigrants by preventing them from immigrating.
} 
without rendering itself illiberal, because the freedom of speech restrictions are ripe for abuse. Joshi cites John Stuart Mill's arguments in On Liberty and elsewhere as an example of what motivates these sorts of thoughts.

It's true that the considerations Mill raises point us toward one important aspect of liberal society: there are certain rights that it is very important for a liberal society to protect, because they are crucial to the continued functioning of a liberal society. Free speech is like this. Healthy debate (perhaps) allows people to freely distinguish the good positions from the bad ones, thus allowing society to arrive at good decisions without forcing anyone. However, rights in a liberal society are important for more than just allowing society to continue. They are also important for non-instrumental reasons. My right to free speech must be respected not just because limiting my free speech is liable to turn into limiting many people's free speech, which will eventually harm society as a whole by depriving it of useful oppositional viewpoints. My right to free speech must also be respected because in a liberal society, individual freedoms matter for the sake of those individuals. This is not to say rights are inviolable. It is just to say that we undersell the importance of rights if we take them to merely be the freedoms that we protect because failing to protect them in one case is liable to trigger abuses of power. Rights are also protected for the sake of the individual rightsholders. In fact unless we collapse into a sort of utilitarianism of rights, it is incoherent to say that we respect rights merely for the sake of preventing abuse, because abuse in this case is wrong because it violates rights. Eventually, rights have to matter.

Alternatively, if rights don't have to matter, and if we truly do defend the rights of citizens in a liberal society by pointing out how these rights are important to the continued existence of a liberal society, then we have just admitted the point I have been trying to establish. That is, we have admitted that restrictions on immigration must be done on the basis of weighing 
the costs and benefits to existing citizens and potential immigrants, rather than by pointing to the inviolable right of a liberal society to remain liberal come what may. ${ }^{37}$ In other words, we are back to where we started before Joshi's argument. We have the various rights to which we are committed for instrumental reasons (which, if we are Freiman and Hidalgo, include freedom of movement), and because some of these rights apply to non-citizens, it is at least conceivable that, if respecting these rights will eventually result in an illiberal society, we must accept this, so long as the illiberal society outcome is not worse than the closed borders outcome.

So, if we want to justify an abuse of someone's rights in a liberal society, whether this person is a citizen or not, it is insufficient to point out that, in some hypothetical cases, we could deprive citizens of this right without risking further abuse of the policy according to which the deprivation is carried out. We have to justify this deprivation in light of the fact that rights violations are generally bad and should be avoided if possible, or in light of the fact that we have balanced the rights on both sides and decided against the immigrants. This is not to say that this justification cannot be provided in the case of a liberal society facing illiberality in light of many potential immigrants or that the interest balancing will always tell in favor of the immigrants. It is just to say that the justification can't entirely ignore the rights violations attendant to each refusal to admit an immigrant any more than it can ignore the rights violation attendant to a policy that violates rights of existing citizens, and it can't just assume that the immigrants will always lose the balancing test.

The third theoretical difficulty for Joshi's argument is that it hinges on the hypothetical situation in which one hundred million immigrants threaten the liberal state of ten million. Ginning up worrying cases like this is easy. The harder task is explaining why these imaginary

\footnotetext{
${ }^{37}$ An argument Joshi might make is that there is some distinction between immigrants and existing citizens such that justification is owed only to the latter and not to the former. This would be to commit the error that Johann Frick refers to as 'double-jeopardy.' See Frick, "National Partiality, Immigration, and the Problem of Double-Jeopardy."
} 
cases (as opposed to other imaginary cases, or actual cases) should dictate our thinking about liberalism's commitments more broadly. Just finding a situation where we think liberalism isn't committed to its own demise is insufficient. We have to rule out the possibility of situations where liberalism is committed to its own demise. Joshi may be perfectly right that liberalism is not committed to its own demise when its demise comes in the form of one hundred million illiberal immigrants, but does this show that liberalism is not committed to its demise in any cases? Does this even show that liberalism is not at least potentially committed to its own demise, or the risk of it, in the actual circumstances we are in?

The lesson is that merely by admitting that there are tradeoffs in freedom to be made, we do not guarantee that the tradeoff tells in favor of preserving liberalism. Preserving liberalism may come at too great a cost. It may entail a hundred million rights violations. Or, even worse, it may be impossible. So, to show that liberalism is not committed to its own demise requires more than just noting that it's not practical for a liberal state to violate the rights of many citizens without this leading to further abuses, even though the liberal state could violate the rights of a similar number of non-citizens without this leading to further abuses. To show that liberalism is not committed to its own demise requires elaborating a theory of what liberal states owe to outsiders and comparing these duties to what they owe to citizens in order to find out whether the demise of the liberal state would represent a larger rights violation than excluding the immigrants. Whether we say that states owe insiders and outsiders respect for inviolable rights, respect for strong but violable rights, or respect for rights justified on some utilitarian basis, we cannot justify ignoring the rights of outsiders by fiat.

\section{THIS IS NOT A BAD CONCLUSION FOR THE LIBERAL}


This may seem like an unfortunate outcome. Liberalism is at least potentially committed to its own demise. What a bummer! Happily, though, if we investigate the circumstances under which preserving liberalism would come at too great a cost and those under which preserving it is impossible, we realize that this conclusion is not as bitter a pill to swallow as we might have thought. It is one to which we were already committed.

\section{1 'COMMITMENT TO DEMISE’ IS OVERLY STRONG}

The idea of liberalism being 'committed to its own demise' is an ominous one, which is perhaps why Joshi picks this label for the view he aims to combat. This seems to imply, or at least gesture in the direction of, some sort self-destructive goal which open borders liberalism adopts, or to which the open borders liberal is irrevocably committed in all cases merely because of the logic of open borders liberalism itself. But the point turns out to be much more modest. Liberalism's commitment is to individual rights and freedoms, and in certain circumstances (which perhaps obtain only rarely, or only subsequent to injustices) this commitment can make it difficult for the society to remain liberal. This does not mean the society wants to abandon liberalism or will always or inevitably be forced to abandon liberalism. It just means that it's not incoherent to think that liberalism can be committed (in the weak sense) to its own demise. Indeed, commitment to demise in the weak sense isn't really commitment to demise: it's merely commitment to something which is likely to entail demise. Thus a clearer way of putting it is that liberalism isn't committed to preserving itself come what may, since the cost of such a commitment could in principle be anything. ${ }^{38}$ Whatever the plausibility of something like Kant's commitment to his understanding of fiat iusticia, pereat mundus, it is not plausible to accept that

\footnotetext{
${ }^{38}$ I thank David Boonin for suggesting I clarify this point.
} 
we must pay any conceivable price merely to ensure a liberal society remains liberal for some period of time. $^{39}$

Moreover, as noted above, although we can generate circumstances in which a liberal society is faced with this choice, like Joshi's case of millions of illiberal immigrants, we might think a more common case is one in which the liberal society faces not an impossible choice between illiberality via immigration or illiberality via exclusion, but a wider set of choices, like illiberality of some sort versus a policy of providing aid to the country that people are immigrating from, thus allowing the potential immigrants to remain in their own country and to achieve their desired standard of life. That is, although we can in principle generate cases where open borders liberalism (or any other sort of liberalism) is committed to destroying itself, in fact there will probably often be many perfectly liberal responses to dilemmas of immigration, free speech, and other similar conundrums.

Thus, finding out liberalism of any kind (whether it endorses open borders or not) is committed to its own demise is at worst like finding out that the United States constitution has a loophole which allows for the rise of a tyrant. ${ }^{40}$ One is inclined not to worry very much, because the bare existence of this possibility is much less relevant than its likelihood, and we have a lot of evidence that America's system of government is rather resilient. ${ }^{41}$ Similarly, one of liberalism's strengths may be the many ways it finds to keep itself intact without having to compromise on the freedoms that it champions. Free speech, freedom of movement, and so on may in principle hold the seeds of liberalism's destruction, but if we play our cards right, this need not be the case.

\footnotetext{
${ }^{39}$ Kant, "Toward Perpetual Peace," 345/Ak 8:378-9.

${ }^{40}$ Kurt Gödel allegedly discovered one such loophole. See Morris, An Essay on the Modern State 220-1.

${ }^{41}$ Notwithstanding recent events. To the extent that Trump's election and subsequent disrespect for norms has eroded one's trust in America's resiliency, one can substitute some other set of institutions.
} 
Thus if we say that liberalism is committed to its own demise, we don't admit anything we were not already willing to admit, which is that sometimes things might not work out. All liberals, whether they are inclined to endorse open borders or not, agree that rights (including the rights of outsiders) must be given some weight, and that weighty or even perhaps nigh-inviolable rights (either for insiders, or outsiders too) might sometimes spell the end of the liberal state. It is true that, according to open borders liberals like Freiman and Hidalgo, the range of cases in which things might spell the end of the state is larger than for liberals who do not endorse strong rights to freedom of movement. Joshi wants us to read this as a reductio against any form of liberalism which would ever entail its own demise. However, because any form of liberalism can lead to this result, we should not discard a proposal like Freiman and Hidalgo's merely because it admits of the bare possibility of a state becoming illiberal.

\subsection{CIRCUMSTANCES WHICH GIVE RISE TO LIBERALISM’S DEMISE}

Moreover, since this is a conclusion about liberalism generally rather than about any particular liberal society, what we have is less a series of individual commitments to demise and more a sort of collective suicide pact. What I mean is that the nature of the commitment to potential demise shifts if we look at it collectively. If we grant that a liberal society must be committed to its own demise if the alternative is excluding the one hundred million immigrants, then every similarly situated liberal society is equally committed. ${ }^{42}$ There are two ways in which this collective commitment to demise is different from an individual commitment.

First, the liberal citizens of the soon to be illiberal society can immigrate to some other liberal society, thus avoiding almost all the rights infringements that will occur. Of course, we

\footnotetext{
${ }^{42}$ Compare Michael Blake's discussion of fairness and collective state responsibility for accepting immigrants from oppressed countries ("Immigration, Jurisdiction, and Exclusion," 127).
} 
may think people have a right to stay put, for various reasons, although typically this is a right against being forcibly evicted, not a right against having the social norms in one's state shift in an illiberal direction such that emigrating becomes one's preferred option. ${ }^{43}$ But, again, since we must balance the various rights violations against each other, it may sometimes be the case that liberal societies must admit immigrants, and that the results are not as dire as Joshi depicts, because Joshi is ignoring the possibility of the liberal citizens moving to some other state. Notice that even on Joshi's account, the justification for immigration restrictions hinges on the illiberal nature of the immigrants. If liberal people want to immigrate to a liberal society, even Joshi's argument lacks resources to explain why it would be okay to block their immigration. ${ }^{44}$

Second, insofar as the potential immigrants aim to go to any old liberal country, or at least any old prosperous liberal country, there is a potential for spreading out the burden of receiving immigrants, and when this potential exists, there is a fairness requirement that each liberal society take its fair share of immigrants. So if other societies are not meeting this requirement, then a liberal society may have a new reason for blocking immigration: it might be unfair for a liberal society to allow itself to collapse into illiberalism if this is occurring in part because other liberal societies are not doing their fair share. I am not sure this consideration means much, in the end, because when weighed against the ills suffered by potential immigrants who are not allowed to immigrate, it may still get outweighed. But, it might not be outweighed. It could be that fairness only requires a liberal society to admit its fair share of immigrants, or to admit some number greater than its fair share but smaller than the number of immigrants who desire to immigrate. Moreover, fairness might require the immigrants to aim to immigrate to

\footnotetext{
${ }^{43}$ See for instance Oberman, "Immigration, Global Poverty and the Right to Stay"; Stilz, "Occupancy Rights and the Wrong of Removal”; Nine, "A Lockean Theory of Territory"; Miller, "Territorial Rights: Concept and Justification"; Moore, A Political Theory of Territory; Nine, "The Wrong of Displacement."

${ }^{44}$ Cf. Whelan, "Citizenship and Freedom of Movement: An Open Admissions Policy?," 21.
} 
various countries rather than just one, and a violation of this duty on the part of the immigrants may give the liberal society additional justification for refusing some immigrants. For instance, an immigrant may forfeit their right to immigrate to a certain country if they unfairly aim to immigrate to that country rather than some other country they could plausibly immigrate to. The country could then justifiably bar the immigrant from immigrating because the immigrant has forfeited their right. Similarly, a student might forfeit their right to be personally tutored by a TA during office hours if they unfairly choose to attend office hours when many other students also want tutoring rather than choosing to attend other, less busy office hours they could just as easily attend.

In light of these two points, there are three answers we can give in response to the scenario Joshi imagines. First, this might solve the problem entirely, because now the immigrants can spread out equally and keep from rendering any society illiberal. This will be the case if the hundred million immigrants don't desire to go to one specific liberal society but instead merely want to immigrate to a liberal society. It will also be the case if the hundred million immigrants have preferences, but these preferences are spread out over many states rather than focused on one state.

Second, if the problem remains, this may be because the other liberal societies aren't accepting their fair share of immigrants, and this is why the single liberal society is facing demise. Once we incorporate fairness considerations and the possibility of liberal citizens moving to a society that remains liberal, we may find that the problem lies not in liberalism's commitment to its demise but in unfair behavior on the part of liberal societies. It shouldn't surprise us that unfair or otherwise unjustifiable behavior on the part of liberals can sink 
liberalism: if nobody pays their taxes or follows any of the laws, that's it for liberal society. So, a similar conclusion with respect to liberal societies more broadly is not a problem.

Third, we should interrogate the source of the problem in the first place. If we have a world of the rich liberals and the poor illiberals, and the illiberals are so poor and so numerous that they're going to destroy some liberal societies via immigration because the liberal societies are so much nicer than the illiberal ones, it is possible that the liberal societies had a hand in unjustifiably generating this situation in the first place. ${ }^{45}$ Whatever our account of global justice, there's a fair chance that a world in which liberal societies are doing much better than illiberal societies is a world in which the liberal societies at one point failed to live up to their duties, whether these duties are negative duties not to colonize other countries, negative duties not to prevent immigration, or positive duties to aid disadvantaged societies. So, their commitment to their own demise is not a failing of liberalism but rather a result of illiberal actions taken in the past by presently liberal societies.

This third point probably best reflects many cases in our actual world. Most of today's so-called 'liberal' societies got that way in part because of all the benefits they reaped by (illiberally) exploiting many presently illiberal societies and destroying any real chance those societies had of becoming liberal in the way that most existing liberal societies became liberal. ${ }^{46}$ A complete etiology of present illiberalism and its relation to colonialism and other ills is beyond the scope of this article. ${ }^{47}$ However, if it's the case that situations like the hundred million

\footnotetext{
${ }^{45}$ Think for instance of France's colonization of Algeria, Belgium's colonization of the Congo and Rwanda, Britain's exploitation of countless countries, and so on. See Hahn, "The Right to Exclude, Human Rights, and Political Facts," 262.

${ }^{46}$ One might go further and charge existing liberal societies with sustaining and benefitting from an unjust social order which violates the rights of many people in illiberal countries (as in Pogge, World Poverty and Human Rights). And of course if Freiman and Hidalgo are right and liberalism entails open borders, then there are no actual liberal societies today.

${ }^{47}$ See Cole for some discussion of the topic as it relates to immigration specifically (Philosophies of Exclusion, 196202).
} 
illiberal immigrants typically arise in cases of systemic injustice generated and sustained in large part by the 'liberal' societies, then liberalism's commitment to its own demise is an easier pill to swallow. It follows not from some sort of flawed approach to rights, which regards them as inviolable or anything like this, but from the rather pedestrian observation that vast injustice may render it impossible for people to relate to one another under conditions of perfect justice, at least for a while.

This is not to say that, if liberal societies are responsible for creating a situation in which they cannot justifiably prevent immigration and still remain liberal, the liberal societies should allow this immigration. Perhaps an all-things-considered evaluation of the sorts of situations Joshi imagines tells in favor of closing borders. ${ }^{48}$ And it may even be the case that some (or, for the sake of the argument, all) of the existing liberal societies are not responsible for the ills of any of the illiberal societies, in which case they have a better case for closing their borders. The point, though, is that we should not deceive ourselves into thinking that closing borders is thereby automatically rendered liberal. We would not deceive ourselves into thinking that removing rights to free speech from illiberal citizens counted as liberal, even if doing so were all-things-considered justified. We would instead regret that in this case, liberalism failed.

\section{OBJECTIONS}

\footnotetext{
${ }^{48}$ There have been many who have undertaken this sort of balancing test to determine whether liberalism can require closed borders. See for instance Wellman, "Immigration and Freedom of Association"; Blake, "The Right to Exclude"; Blake, "Immigration, Jurisdiction, and Exclusion"; Pevnick, Immigration and the Constraints of Justice; Cole, Philosophies of Exclusion; Carens, "Migration and Morality: A Liberal Egalitarian Perspective." One set of cosmopolitan arguments concerns the prevention of 'brain drain,' although it is not clear that this is best accomplished by restrictions on immigration. See Yuksekdag, "Moral Cosmopolitanism and the Right to Immigration"; Mendoza, "Does Cosmopolitan Justice Ever Require Restrictions on Migration?," 180-83; Donoso and Mancilla, "Doctors with Borders? An Authority-Based Approach to the Brain Drain"; Oberman, "Can Brain Drain Justify Immigration Restrictions?" My own view is that the most plausible theory of justice will entail the permissibility of some immigration restrictions in but that in the vast majority of cases, justice will necessitate open borders.
} 


\subsection{IF LIBERAL STATES CAN JAIL AND QUARANTINE, THEY CAN EXCLUDE}

\section{IMMIGRANTS}

One might argue that of course liberalism can do seemingly illiberal things and still remain liberal, because it's illiberal to lock someone up in jail or quarantine them but doing so does not render a society illiberal. So, my argument must have gone wrong somewhere. ${ }^{49}$ However, a liberal society of course can't always jail anyone or always quarantine anyone. It must weigh the competing rights. It may be that if the competing rights are very high stakes, like life and death for many people, it's obvious that restrictions on liberty like jail or quarantine will always win out. But it's not at all obvious that when the stakes are lower, namely, the continued existence of a state's liberal nature, then restrictions on immigration will always win out. And no matter what the outcome is, the state's duties to the potential prisoner or quarantine patient must be factored in. The state can never lose sight of what its duties are, even if these duties are not attached to inviolable rights. Unless we assume at the outset that the state has no duties to outsiders, like cosmopolitan egalitarian duties to promote justice or libertarian duties to respect their freedom of movement, we cannot simply render a verdict that ignores outsiders in this equation.

This is doubly relevant to exclusion, because we would not think that, because it is okay to jail or quarantine citizens, it is okay to exclude them by denationalizing and deporting them. ${ }^{50}$ In fact, it may be worse to exclude people than to imprison or quarantine them. Imprisonment and quarantine keep a dangerous person from harming others, whereas exclusion allows them to freely inflict their misdeeds or infection on others. So, it might be worse to exclude illiberal

\footnotetext{
${ }^{49}$ A similar argument one step down the line would be that a liberal state has to admit some people, but it must be able to exclude some in order to preserve itself, just like it is acceptable to ration limited health care resources even if there is a duty to treat some people. For a discussion of this argument in the context of immigration, see Cole, Philosophies of Exclusion, 148-54.

${ }^{50}$ Gibney, "Should Citizenship Be Conditional? The Ethics of Denationalization," 656.
} 
insiders than to treat them some other way. In fact, it might be wrong for a liberal society to refuse to accept illiberal immigrants. Those illiberal immigrants have to live somewhere, and thus there's no way to get around their illiberal opinions. It might be incumbent on the liberal society to accept them if other considerations tell in favor of this (like the desire of the illiberal people to live there, rather than where they are). It may not be okay for the liberal society to claim a prerogative for itself to avoid illiberalism if this requires inflicting illiberalism on some other society. ${ }^{51}$

\subsection{IF THERE IS A RIGHT TO A LIBERAL STATE, THIS SOLVES THE BALANCING PROBLEM}

I have argued that to determine if liberalism must be committed to its own destruction, we must weigh up the rights on both sides. One might argue that any time we do this, preservation of liberalism will win out, because the citizens in the liberal state have a right to the continuation of a liberal state. For instance, Sune Lægaard suggests that, from the point of view of Andrew Altman and Christopher Heath Wellman, it could potentially be justifiable to restrict immigration if this would prevent the state from performing the requisite political functions, which are upholding human rights. ${ }^{52}$ One could then argue that there is a human right to a liberal state. Thus immigration restrictions would be justified on the basis of protecting the state's ability to uphold this particular human right.

\footnotetext{
${ }^{51}$ This argument works not just for evaluating a liberal society's duty to accept immigrants, but also for evaluating a liberal society's duty not to denationalize existing citizens. On this latter point, see Patti Tamara Lenard's argument against revoking citizenship ("Democracies and the Power to Revoke Citizenship," 87-88) and Miller's discussion of the same ("Democracy, Exile, and Revocation," 269-70).

${ }^{52}$ Lægaard, "Territorial Rights, Political Association, and Immigration," 653-54; Altman and Wellman, A Liberal Theory of International Justice.
} 
At most, though, a right to a liberal state is not the only human right. If a state must violate other human rights in order to protect that right, we are either in a situation where the state cannot remain legitimate (and presumably cannot remain liberal) or we must again engage in the balancing act. We may have a little more to put on the scales in terms of preserving the liberal nature of the state, but this hardly solves the balancing problem. It just gives us one more thing to think about. ${ }^{53}$

\subsection{ILLIBERAL PEOPLE FORFEIT THEIR RIGHT TO IMMIGRATE}

I suggested above that if immigrants unfairly aim to immigrate to certain states, this may be a reason for thinking that they have forfeited their right to immigrate to those states. One might try to generalize this argument by arguing that people who aim to act on illiberal norms and who, in doing so, will render a society illiberal, have forfeited their right to immigrate to that liberal society. This would be because acting illiberally would be a way of forfeiting one's right to immigrate, or at least one's right to immigrate to a liberal society. ${ }^{54}$

One issue with this argument is that it is not clear why aiming to act in illiberal ways leads to forfeiting one's right to freely move, or one's right to avoid genocide by escaping one's country, or any of the other sort of rights that go into the balancing equation to determine whether a liberal society must allow people to immigrate. The larger issue, though, is that it is again just at best one more thing to throw into the balancing, rather than an explanation for why liberalism cannot be committed to its own destruction. Here is why. If this argument works, it

\footnotetext{
${ }^{53}$ Altman and Wellman themselves note that the right to exclude immigrants is a pro tanto right - that is, they agree that it must be balanced against other considerations. See Altman and Wellman, 161.

${ }^{54}$ On rights forfeiture more generally see Wellman's defense of a rights forfeiture theory of punishment (Rights Forfeiture and Punishment). Wellman's theory very specifically argues that people only forfeit their rights with respect to punishment, and thus it does not license anything like the argument described here (although it might potentially license a similar argument that justifies taking away rights from or denationalizing and excluding existing members of liberal societies).
} 
works for a single illiberal person aiming to immigrate into a huge liberal society. In this circumstance, this person has no hope of rendering that society illiberal. This shows that the rights forfeiture in this situation is orthogonal to whether the potential immigrant is or is not liable to render the society illiberal.

One further issue with rights forfeiture is that it also seems to license exclusion of existing illiberal citizens, which seems objectionable. Whatever could explain a forfeiture of the right to immigrate on the part of illiberal outsiders would also explain a forfeiture of the right to remain on the part of illiberal insiders. So, we may want to be cautious about appealing to a rights forfeiture argument to block immigration, lest we justify too much. ${ }^{55}$

\section{CONCLUSION}

The conclusion is this: to find out whether they can exclude potential immigrants, liberal societies need a theory of global justice that elucidates all the relevant rights and duties, such that the society can balance what it owes to the immigrants against what would happen if they were allowed in. Practically any plausible theory of justice will suggest that if it's a matter of life and death for millions of refugees, then liberal society loses out, doubly so if the illiberal society that results will be relatively decent, like for instance if it will be decent in the technical sense of the term used by Rawls. ${ }^{56}$ Theories of justice that entail strong duties to outsiders, like cosmopolitan global egalitarianism or strict libertarianism, may also require letting in many illiberal immigrants. Theories of justice that take into account past injustices visited upon illiberal societies by liberal societies, and that are to a large degree responsible for the fact that the immigrants want to immigrate in the first place, will likely tell in favor of allowing at least some

\footnotetext{
${ }^{55}$ For a more extensive discussion of exclusion and its relationship to arguments against open borders, see my "Territorial Exclusion: An Argument against Closed Borders."

${ }^{56}$ Rawls, The Law of Peoples.
} 
of them in. Theories that allow for favoring one's compatriots for one reason or another could give arguments for preventing immigration. ${ }^{57}$ And so on. Here I have just aimed to show that a commitment to liberalism's demise is not a reductio against liberals who endorse open borders. We cannot simply assume from the outset that a liberal society cannot be committed to destroying itself. To do so would beg the question against open borders liberals, but, as I have argued, it would ignore the fact that any liberal view must admit the possibility that a liberal society could face insurmountable challenges.

Ashoka University

\section{REFERENCES}

Abizadeh, Arash. "Democratic Theory and Border Coercion: No Right to Unilaterally Control Your Own Borders." Political Theory 36, no. 1 (2008): 37-65.

—_ "On the Demos and Its Kin: Nationalism, Democracy, and the Boundary Problem." American Political Science Review 106, no. 4 (2012): 867-82.

Akhtar, Sahar. "Stripping Citizenship: Does Membership Have Its (Moral) Privileges?" Australasian Journal of Philosophy 95, no. 3 (2017): 419-34.

Altman, Andrew, and Christopher Heath Wellman. A Liberal Theory of International Justice. New York: Oxford University Press, 2009.

Arneson, Richard J. "Extreme Cosmopolitanisms Defended." Critical Review of International Social and Political Philosophy 19, no. 5 (2016): 555-73.

Banai, Ayelet. "Self-Determination and Resource Rights: In Defence of Territorial Jurisdiction Over Natural Resources." Res Publica 22, no. 1 (2016): 9-20.

Blake, Michael. "Immigration, Jurisdiction, and Exclusion." Philosophy and Public Affairs 41, no. 2 (2013): 103-30.

_. "The Right to Exclude." Critical Review of International Social and Political Philosophy 17, no. 5 (2014): 521-37.

Bosniak, Linda. "Being Here: Ethical Territoriality and the Rights of Immigrants." Theoretical Inquiries in Law 8, no. 2 (2007): 389-410.

\footnotetext{
${ }^{57}$ See for instance Miller, Strangers in Our Midst.
} 
Buchanan, Allen. 1991. Secession: The Morality of Political Divorce from Fort Sumter to Lithuana and Quebec. Boulder: Westview Press.

Buckinx, Barbara, and Alexandra Filindra. "The Case against Removal: Jus Noci and Harm in Deportation Practice.” Migration Studies 3, no. 3 (2015): 393-416.

Carens, Joseph. "Migration and Morality: A Liberal Egalitarian Perspective." In Free Movement: Ethical Issues in the Transnational Migration of People and Money, edited by Brian Barry and Robert E. Goodin, 25-47. University Park, Pennsylvania: The Pennyslvania State University Press, 1992.

\section{—. The Ethics of Immigration. New York: Oxford University Press, 2013.}

Christiano, Thomas. “Immigration, Political Community, and Cosmopolitanism.” San Diego Law Review 45, no. 4 (2008): 933-62.

CNN. "Trump Praises 'Operation Wetback.”” YouTube Video, November 11, 2015. https://www.youtube.com/watch?v=n7UuuEFPGN0

Cole, Phillip. Philosophies of Exclusion: Liberal Theory and Immigration. Edinburgh: Edinburgh University Press Ltd, 2000.

Donoso, Alfonso, and Alejandra Mancilla. "Doctors with Borders? An Authority-Based Approach to the Brain Drain." South African Journal of Philosophy 36, no. 1 (2017): 69-77.

Fabre, Cécile. "Peace, Self-Determination and Reckoning with the Past: A Reply to Butt, Lippert-Rasmussen, Pasternak, Wellman and Stemplowska." Journal of Applied Philosophy 36, no. 3 (2019): 391-404.

Ferracioli, Luara. "Citizenship Allocation and Withdrawal: Some Normative Issues." Philosophy Compass 12, no. 12 (2017): 1-9.

. "Citizenship for Children: By Soil, by Blood, or by Paternalism?” Philosophical Studies 175, no. 11 (2017): 2859-77.

Freiman, Christopher, and Javier Hidalgo. "Liberalism or Immigration Restrictions, But Not Both." Journal of Ethics \& Social Philosophy 10, no. 2 (2016).

Frick, Johann. "National Partiality, Immigration, and the Problem of Double-Jeopardy." In Oxford Studies in Political Philosophy, edited by David Sobel, Peter Vallentyne, and Steven Wall, Vol. 6: 151-83. Oxford: Oxford University Press, 2020.

Gibney, Matthew J. "Should Citizenship Be Conditional? The Ethics of Denationalization." Journal of Politics 75, no. 3 (2013): 646-58.

Hahn, Henning. "The Right to Exclude, Human Rights, and Political Facts." Moral Philosophy and Politics 3, no. 2 (2016): 247-67. 
Holt, Kris. "CBP Flew A Predator Drone Over Minneapolis Amid George Floyd Protests." Forbes, May 29, 2020. https://www.forbes.com/sites/krisholt/2020/05/29/cbp-predatordrone-minneapolis-george-floyd-aclu

Huemer, Michael. "Is There a Right to Immigrate?" Social Theory and Practice 36, no. 3 (2010): 429-61.

Jones, Tom, Mari Payton and Bill Feather. "Source: Leaked Documents Show the U.S. Government Tracking Journalists and Immigration Advocates Through a Secret Database." CNN San Diego, March 16, 2019. https://www.nbcsandiego.com/news/local/source-leakeddocuments-show-the-us-government-tracking-journalists-and-advocates-through-a-secretdatabase $/ 3438 /$

Joshi, Hrishikesh. "Is Liberalism Committed to Its Own Demise?" Journal of Ethics and Social Philosophy 13, no. 3 (2018): 259-67.

Kant, Immanuel. "Toward Perpetual Peace." In Practical Philosophy, translated and edited by Mary J. Gregor, 311-51. Cambridge: Cambridge University Press, 1996.

Kymlicka, Will. Multicultural Citizenship. Oxford: Oxford University Press, 1995.

Lægaard, Sune. “Territorial Rights, Political Association, and Immigration.” Journal of Moral Philosophy 10, no. 5 (2013): 645-70.

Lenard, Patti Tamara. "Democracies and the Power to Revoke Citizenship." Ethics and International Affairs 30, no. 1 (2016): 73-91.

Lindauer, Matthew. "Immigration Policy and Identification across Borders." Journal of Ethics and Social Philosophy 12, no. 3 (2017): 280-303.

Mendoza, José Jorge. "Does Cosmopolitan Justice Ever Require Restrictions on Migration?" Public Affairs Quarterly 29, no. 2 (2015): 175-86.

_. "Enforcement Matters: Reframing The Philosophical Debate over Immigration." Journal of Speculative Philosophy 29, no. 1 (2015): 73-90.

Miklosi, Zoltan. "Immigration and the Democratic Stability Argument." Moral Philosophy and Politics 3, no. 2 (2016): 289-312.

Miller, David. "Democracy, Exile, and Revocation." Ethics and International Affairs 30, no. 2 (2016): 265-70.

—. National Responsibility and Global Justice. New York: Oxford University Press, 2007.

—. On Nationality. Oxford: Clarendon Press, 1995.

—. Strangers in Our Midst. Cambridge, Mass: Harvard University Press, 2016.

—. "Territorial Rights: Concept and Justification.” Political Studies 60, no. 2 (2012): 252- 
68.

Moltchanova, Anna. "Cooperation in the We-Mode and Immigrant Inclusion." Journal of Value Inquiry 50, no. 1 (2016): 83-96.

Moore, Margaret. A Political Theory of Territory. New York: Oxford University Press, 2015.

Morris, Christopher. 1998. An Essay on the Modern State. Cambridge: Cambridge University Press.

Nine, Cara. “A Lockean Theory of Territory.” Political Studies 56, no. 1 (2008): 148-65.

- "The Wrong of Displacement: The Home as Extended Mind." Journal of Political Philosophy 26, no. 2 (2018): 240-57.

Oberman, Kieran. “Can Brain Drain Justify Immigration Restrictions?” Ethics 123, no. 3 (2013): 427-55.

_ "Immigration, Global Poverty and the Right to Stay." Political Studies 59, no. 2 (2011): 253-68.

Ochoa Espejo, Paulina. "Taking Place Seriously: Territorial Presence and the Rights of Immigrants." Journal of Political Philosophy 24, no. 1 (2016): 67-87.

Pevnick, Ryan. Immigration and the Constraints of Justice: Between Open Borders and Sovereignty. Cambridge: Cambridge University Press, 2011.

Pogge, Thomas. World Poverty and Human Rights. 2nd ed. Cambridge: Polity, 2008.

Rawls, John. The Law of Peoples. Cambridge, Mass: Harvard University Press, 1999.

Reston, Maeve. "How Trump's Deportation Plan Failed 62 Years Ago.” CNN, January 19, 2016. https://edition.cnn.com/2016/01/19/politics/donald-trump-deportation-mexicoeisenhower/index.html

Schutter, Helder De, and Lea Ypi. "Mandatory Citizenship for Immigrants." British Journal of Political Science 45, no. 2 (2013): 235-51.

Serwer, Adam. "Jeff Sessions's Unqualified Praise for a 1924 Immigration Law." The Atlantic, January 10, 2017. https:/www.theatlantic.com/politics/archive/2017/01/jeff-sessions-1924immigration/512591/

Stilz, Anna. "Occupancy Rights and the Wrong of Removal." Philosophy and Public Affairs 41, no. 4 (2013): 324-56.

—. "Settlement, Expulsion, and Return.” Politics, Philosophy \& Economics 16, no. 4 (November 18, 2017): 351-74.

Waldron, Jeremy. “Theoretical Foundations of Liberalism.” Philosophical Quarterly 37, no. 147 
(1987): 127-50.

Walzer, Michael. Spheres of Justice: A Defense of Pluralism and Equality. New York: Basic Books, 1983.

Wellman, Christopher Heath. "Immigration and Freedom of Association." Ethics 119, no. 1 (2008): 109-41.

—. Rights Forfeiture and Punishment. Oxford: Oxford University Press, 2017.

Weltman, Daniel. "Territorial Exclusion: An Argument against Closed Borders." Journal of Ethics and Social Philosophy, forthcoming.

Whelan, Frederick. "Citizenship and Freedom of Movement: An Open Admissions Policy?" In Open Borders? Closed Societies? The Ethical and Political Issues, edited by Mark Gibney, 3-39. New York: Greenwood Press, 1988.

Yuksekdag, Yusuf. "Moral Cosmopolitanism and the Right to Immigration." Public Reason 4, no. 1-2 (2012): 262-72.

I thank two anonymous reviewers from the Journal of Global Ethics, Eric Palmer and Christine Koggel in their capacity as editors of the Journal of Global Ethics, an anonymous reviewer from this journal, and David Boonin in his capacity as editor for this journal for their comments on this paper. 